\title{
Tyrphostin A8
}

National Cancer Institute

\section{Source}

National Cancer Institute. Tyrphostin A8. NCI Thesaurus. Code C2025.

A member of the tyrphostin family of tyrosine kinase inhibitors that inhibits the GT Pase activity of transducin and competitively inhibits calcineurin activity. $(\mathrm{NCl})$ 